\title{
New encounters in Arctic waters: a comparison of metabolism and performance of polar cod (Boreogadus saida) and Atlantic cod (Gadus morhua) under ocean acidification and warming
}

\author{
Kristina Lore Kunz ${ }^{1,2,3}$ (D) Stephan Frickenhaus ${ }^{4,5} \cdot$ Silvia Hardenberg ${ }^{6}$. \\ Torild Johansen $^{7}$ - Elettra Leo ${ }^{2,3} \cdot$ Hans-Otto Pörtner ${ }^{2,3} \cdot$ Matthias Schmidt $^{2,3}$. \\ Heidrun Sigrid Windisch ${ }^{8} \cdot$ Rainer Knust $^{1} \cdot$ Felix Christopher Mark ${ }^{2}$
}

Received: 16 October 2015/Revised: 9 March 2016/Accepted: 14 March 2016/Published online: 24 March 2016

(C) Springer-Verlag Berlin Heidelberg 2016

\begin{abstract}
Oceans are experiencing increasing acidification in parallel to a distinct warming trend in consequence of ongoing climate change. Rising seawater temperatures are mediating a northward shift in distribution of Atlantic cod (Gadus morhua), into the habitat of polar cod (Boreogadus saida), that is associated with retreating cold water masses. This study investigates the competitive strength of the co-occurring gadoids under ocean acidification and warming (OAW) scenarios. Therefore, we incubated specimens of both species in individual tanks for 4 months, under different control and projected temperatures (polar
\end{abstract}

Electronic supplementary material The online version of this article (doi:10.1007/s00300-016-1932-z) contains supplementary material, which is available to authorized users.

Kristina Lore Kunz

Kristina.Kunz@awi.de

Stephan Frickenhaus

Stephan.Frickenhaus@awi.de

Silvia Hardenberg

silvia.hardenberg@zmt-bremen.de

Torild Johansen

Torild.Johansen@imr.no

Elettra Leo

Elettra.Leo@awi.de

Hans-Otto Pörtner

Hans.Poertner@awi.de

Matthias Schmidt

Matthias.Schmidt@awi.de

Heidrun Sigrid Windisch

Heidrun.Windisch@hhu.de

Rainer Knust

Rainer.Knust@awi.de

Felix Christopher Mark

Felix.Christopher.Mark@awi.de cod: $0,3,6,8{ }^{\circ} \mathrm{C}$, Atlantic cod: $3,8,12,16{ }^{\circ} \mathrm{C}$ ) and $\mathrm{PCO}_{2}$ conditions (390 and $1170 \mu \mathrm{atm})$ and monitored growth, feed consumption and standard metabolic rate. Our results revealed distinct temperature effects on both species. While hypercapnia by itself had no effect, combined drivers caused nonsignificant trends. The feed conversion efficiency of normocapnic polar cod was highest at $0{ }^{\circ} \mathrm{C}$, while optimum growth performance was attained at $6^{\circ} \mathrm{C}$; the long-term upper thermal tolerance limit was reached at $8{ }^{\circ} \mathrm{C}$. OAW caused only slight impairments in growth performance. Under normocapnic conditions, Atlantic cod consumed progressively increasing amounts of feed than individuals under hypercapnia despite maintaining similar growth rates during warming. The low feed conversion

1 Bentho-Pelagic Processes, Alfred Wegener Institute Helmholtz Centre for Polar and Marine Research, Am Alten Hafen 26, 27568 Bremerhaven, Germany

2 Integrative Ecophysiology, Alfred Wegener Institute Helmholtz Centre for Polar and Marine Research, Am Handelshafen 12, 27570 Bremerhaven, Germany

3 University of Bremen, Fachbereich 2, NW 2/Leobener Strasse, 28359 Bremen, Germany

4 Scientific Computing, Alfred Wegener Institute Helmholtz Centre for Polar and Marine Research, Am Handelshafen 12, 27570 Bremerhaven, Germany

5 Hochschule Bremerhaven, An der Karlstadt 8, 27568 Bremerhaven, Germany

6 Leibniz Center for Tropical Marine Ecology (ZMT), Fahrenheitstrasse 6, 28359 Bremen, Germany

7 Institute of Marine Research, Sykehusveien 23, 9294 Troms $\varnothing$, Norway

8 Institute for Cell Biology and Zoology, Heinrich-HeineUniversity, Universitätsstrasse 1, 40225 Düsseldorf, Germany 
efficiency at $3{ }^{\circ} \mathrm{C}$ may relate to the lower thermal limit of Atlantic cod. In conclusion, Atlantic cod displayed increased performance in the warming Arctic such that the competitive strength of polar cod is expected to decrease under future OAW conditions.

Keywords Climate change - Gadoids - Hypercapnia Thermal window - Growth · Feed consumption - RCP 8.5

\section{Introduction}

The oceans are currently experiencing rising water temperatures, and in parallel, the increase in atmospheric $\mathrm{CO}_{2}$ concentrations causes ocean acidification. By the year 2100, global water surface temperatures are expected to rise by $2-3{ }^{\circ} \mathrm{C}$ paralleled by $\mathrm{PCO}_{2}$ levels of up to $1370 \mu \mathrm{atm}$ depending on future emission scenarios (RCP 8.5, Pörtner et al. 2014). Due to a higher solubility of $\mathrm{CO}_{2}$ in cold waters and the freshening of surface waters, Arctic ecosystems more than other ecosystems are expected to be impaired by climate change. Organisms inhabiting high Arctic environments are in general well adapted to polar conditions; however, their narrow thermal windows imply high vulnerability under changing abiotic conditions.

The distribution of fish species is constrained by their species-specific temperature ranges (Coutant 1977; Pörtner 2002; Pörtner and Knust 2007; Pörtner and Peck 2010). Warming oceans cause a general trend of poleward movement of fish species (Brander et al. 2003; Parmesan 2006 and references therein) as reported for the Barents Sea (Drinkwater 2009), the North Sea (Perry et al. 2005), and the Bering Sea (Grebmeier et al. 2006). Invading species have a high potential to establish themselves in the previously colder areas as predicted by Parmesan (2006), provided that food availability, food quality, and potential spawning grounds support their settlement (Drinkwater 2005). Competition between invading and endemic taxa may alter well-established ecosystem structures and can force the local species to migrate into habitats with less favorable conditions (Renaud et al. 2012) thereby impairing fitness components such as growth and reproduction (Koehn and Shumway 1982). Ultimately, if under those conditions the long-term metabolic energy demand exceeds food supply (Brett 1979), growth and then population density will decline (Planque and Frédou 1999; Clark et al. 2003; Brander 2007).

Atlantic cod (Gadus morhua) (Perry et al. 2005; Drinkwater 2009) inhabits a broad geographical and thus thermal range (Scott 1982; Brander 1994, 1995), even within its different stocks (Malmberg and Blindheim 1994; Ottersen et al. 1998). Due to increasing water temperatures, Atlantic cod shift their habitat to the North (Kjesbu et al.
2014). The northernmost distribution boundary currently comprises the waters around Svalbard (Olsen et al. 2010). There, Atlantic cod co-occur with the resident polar cod (Boreogadus saida) (Renaud et al. 2012), which are associated with the retreating cold Arctic water masses (Gjøsæter 2009). Although direct competition for food is considered marginal (Renaud et al. 2012), potential interspecific interactions may occur via competition for space. Moreover, predation on polar cod is likely to increase with increasing abundance of Atlantic cod in Arctic waters (Renaud et al. 2012).

While Atlantic cod is one of the most exploited fish species in the North Atlantic (Drinkwater 2005; Brander 2010) and an important predator species (Björnsson et al. 2001), the most pronounced value of polar cod lies in its function as a prey species for several taxa including economically important fish species (Sekerak 1982; Bradstreet et al. 1986; Welch et al. 1993; Gjøsæter 2009). Any change in population size of one or both of these species may therefore have economic consequences together with unpredictable ecological interferences.

Individual growth and reproduction are the driving forces shaping population growth. Growth relies on excess energy which becomes available after baseline metabolic costs have been met. Later in life, beyond a specific body size, energy is required for gonadal development and reproduction (Pörtner et al. 2005).

Surplus energy for growth and reproduction, however, is only available within a species-specific temperature range. Within this range, the thermally stimulated appetite and food uptake support energy allocation to growth, linked to a species-specific optimum temperature for aerobic performance. At temperatures above the optimum for growth, food uptake is increasingly used to cover the exponentially increasing metabolic demands, resulting in declining growth rates (Brett 1979).

The interactions of growth, metabolic performance, and hypercapnia have mainly been studied in an aquaculture context at $\mathrm{PCO}_{2}$ values far exceeding values projected for the open ocean (e.g. Fivelstad et al. 1998, 1999; Foss et al. 2003; Moran and Støttrup 2011). But even under realistic $\mathrm{PCO}_{2}$ scenarios $(700 \mu \mathrm{atm})$, reduced growth rates were found e.g., for Atlantic salmon parr (Fivelstad et al. 2007). According to the concept of oxygen- and capacity-limited thermal tolerance (OCLTT), narrower thermal windows and possibly lower performance optima have been proposed to occur under hypercapnia (Pörtner 2010). Furthermore, increased $\mathrm{PCO}_{2}$ has been reported to reduce food consumption (Smart 1981; Crocker and Cech 1996; Foss et al. 2003) and at the same time may increase metabolic energy demand (Fivelstad et al. 2007).

Many studies report the effects of individual environmental stressors on the physiology of fish species, 
especially in economically important species like Atlantic cod (e.g. Björnsson et al. 2001; Purchase and Brown 2001; Moran and Støttrup 2011). Knowledge of chronic and synergistic effects of ocean warming and acidification on the performance and fitness of fish species is still scarce, especially with respect to realistic future ocean conditions.

The aim of this study was to investigate the combined effects of projected ocean warming and acidification on growth performance, feed consumption, and standard metabolic rate in populations of two co-occurring gadoids, polar cod and Atlantic cod at their overlapping distribution ranges in the Arctic. The results are used to assess the competitive strength of both polar cod and Atlantic cod under projected water conditions. We discuss our findings in light of their ecology and the conditions faced by the species in their natural habitat.

\section{Materials and methods}

\section{Sample collection}

The polar cod used in this study were provided by the University of Troms $\varnothing$, Norway. In January 2013, polar cod were caught from the R/V Helmer Hanssen with a bottom trawl in a depth of $120 \mathrm{~m}$ in Kongsfjorden $\left(78^{\circ} 97^{\prime} \mathrm{N} 12^{\circ}\right.$ $\left.51^{\prime} \mathrm{E}\right)$ at the western coast of Svalbard. By aid of a fish lift (Holst and McDonald 2000), injuries during trawling were prevented. However, a mortality of approx. $50 \%$ was recorded within the first week after capture. Size at capture was approx. 6-7 cm. The fish were kept in a flow-through seawater tank while being transported to the laboratories of Havbruksstasjonen i Troms $\emptyset$ AS (HiT) and kept until April 2013 at $3.3-3.8^{\circ} \mathrm{C}$ under natural light conditions. They were fed three times a week with frozen copepods (Calanus spec.). In late April 2013, 150 individuals were transferred to the aquaria of the Alfred Wegener Institute (AWI) in Bremerhaven. In preparation for transportation, the fish were starved for a week.

The recirculating aquaria system at the AWI contained $10 \mathrm{~m}^{3}$ of seawater originating from the North Sea near Helgoland (German Bight). Nitrification filters, protein skimmers and UV sterilizers as well as additional water changes were used to support high water quality and $\mathrm{NO}_{3}{ }^{-}$ values below $50 \mathrm{mg} \mathrm{L}^{-1}$. For preconditioning, the fish were kept at $5{ }^{\circ} \mathrm{C}$ for another 4 weeks. Starting one day after arrival, the polar cod were weaned onto a daily feeding pattern with high-protein feed pellets (Amber Neptun, $5 \mathrm{~mm}$, Skretting AS, Norway). The light cycle was adjusted to $12 \mathrm{~h}$ of light and $12 \mathrm{~h}$ of darkness (12L:12D).

In August 2013, Atlantic cod were caught from the R/V Heincke at several locations in the vicinity of Svalbard: Rijpfjorden $\left(80^{\circ} 15.42^{\prime} \mathrm{N} 22^{\circ} 12.89^{\prime} \mathrm{E}\right)$, Hinlopenstretet $\left(79^{\circ} 30.19^{\prime} \mathrm{N} \quad 18^{\circ} 57.51^{\prime} \mathrm{E}\right), \quad$ and $\quad$ Forlandsundet $\left(78^{\circ} 54.60^{\prime} \mathrm{N} 11^{\circ} 3.66^{\prime} \mathrm{E}\right)$ using a pelagic midwater trawl combined with a fish lift (Holst and McDonald 2000) at a depth of 0-40 m. Size at capture was approx. 5-7 cm. The fish were directly transported in a thermostatted recirculating tank system $\left(4 \mathrm{~m}^{3}\right)$ to the AWI aquaria in Bremerhaven and kept for several months at $5{ }^{\circ} \mathrm{C}$. Mortality during capture was low; however, cannibalism decreased the numbers of specimens substantially. They were fed twice a week with a mixture of frozen copepods, baby krill, and high-protein feed pellets.

\section{Experimental design}

The experimental design consisted of eight different stable temperature $/ \mathrm{PCO}_{2}$ treatments, each containing 12 single aquaria (approx. $24 \mathrm{~L}$ each). The chosen temperatures (polar cod: $0,3,6,8^{\circ} \mathrm{C}$; Atlantic cod: $3,8,12,16^{\circ} \mathrm{C}$ ) were based on the range of habitat temperatures and were maintained by the aid of thermostatted rooms. For each temperature, two $\mathrm{PCO}_{2}$ levels were applied comprising the current conditions $\left[390 \mu \mathrm{atm}=\right.$ control $\quad \mathrm{PCO}_{2} ;$ mean actual values: $430 \mu \mathrm{atm}$ (polar cod), $480 \mu \mathrm{atm}$ (Atlantic cod), Tables 1,2] as well as a future value projected by the turn of the century $\left[1170 \mu \mathrm{atm}=\right.$ high $\mathrm{PCO}_{2}$; mean actual values: $1100 \mu \mathrm{atm}$ (polar cod), $1120 \mu \mathrm{atm}$ (Atlantic cod), Tables 1, 2] according to the Representative Concentration Pathway (RCP) 8.5 of the Intergovernmental Panel on Climate Change (IPCC) (Pörtner et al. 2014). For equal conditions across individual aquaria within the treatments, the respective $\mathrm{PCO}_{2}$ conditions were pre-adjusted in a header tank containing approximately $200 \mathrm{~L}$ of seawater, supplying the single aquaria. The manipulation of $\mathrm{CO}_{2}$ partial pressure was achieved by use of a mass flow controller (4 and 6 channel MFC system, HTK, Hamburg, Germany), in which virtually $\mathrm{CO}_{2}$-free pressurized air was mixed with pure $\mathrm{CO}_{2}$. This setup was identical for both species. It should be noted that this protocol differs from those traditionally applied in culture systems comprising a group of specimens in a common tank under the same environmental regime.

At the end of May 2013, 96 polar cod with a total length of $10.9-17.3 \mathrm{~cm}$ (mean length $14.2 \mathrm{~cm} \pm 1.3 \mathrm{SD}$ ) and a weight of 6.7-31.9 $\mathrm{g}$ (mean weight $16.8 \mathrm{~g} \pm 5.6 \mathrm{SD}$ ) were transferred to the experimental setup. Cooling and warming protocols were applied at a maximum rate of $2{ }^{\circ} \mathrm{C}$ per $24 \mathrm{~h}$. To ensure proper technical replicates during allocation to experimental conditions, the distribution of individuals across temperatures, as well as $P \mathrm{CO}_{2}$ regimes, was random. Each individual was placed into a single aquarium with an individual inflow of $500 \mathrm{~mL} \mathrm{~min}{ }^{-1}$.

The experiment with 96 Atlantic cod started in the end of April 2014. The size range was $14.2-24.8 \mathrm{~cm}$ (mean 


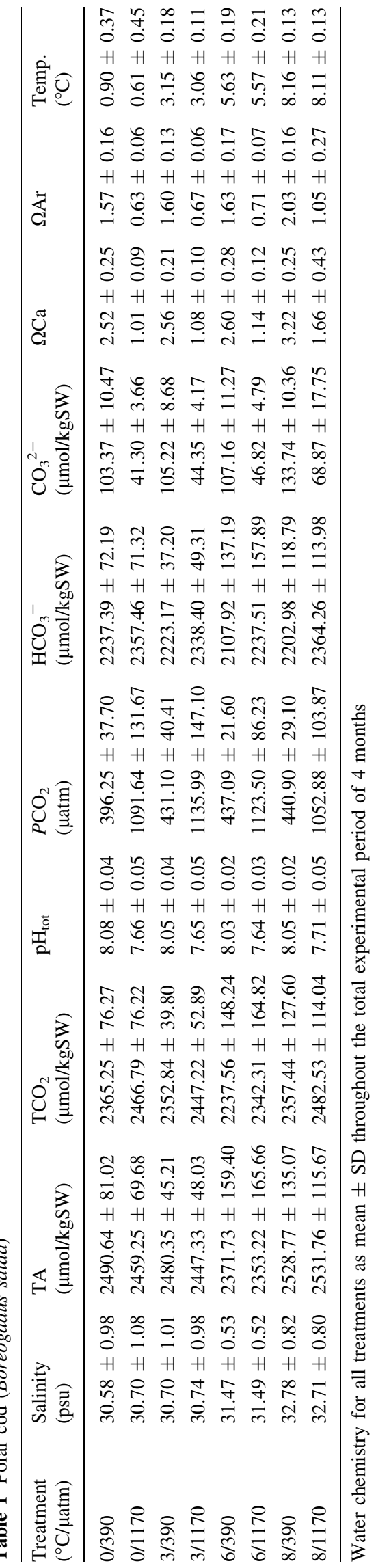

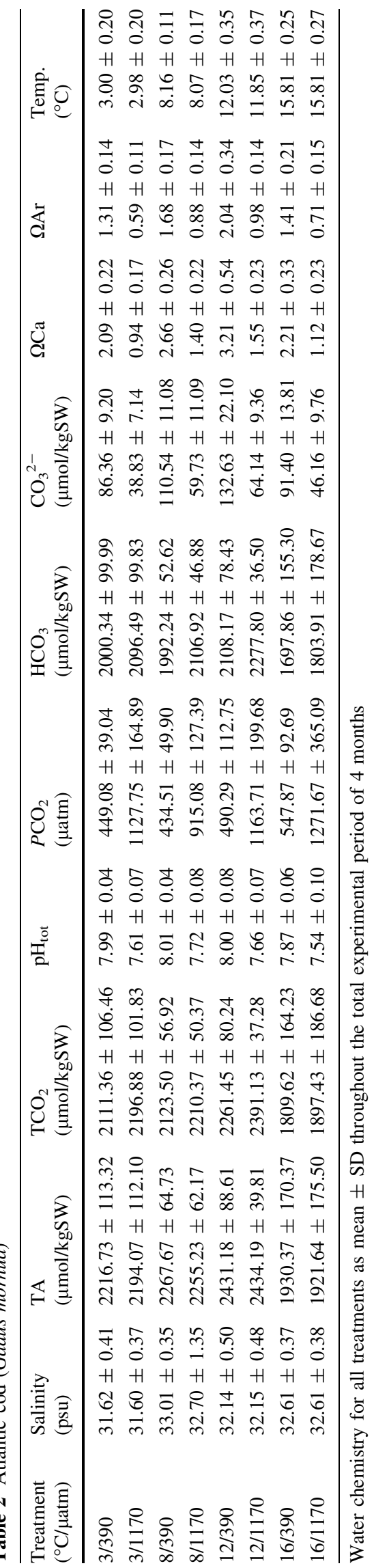


total length $18.5 \mathrm{~cm} \pm 2.2 \mathrm{SD})$ and weight was 15.3-103.8 g (mean weight $43.4 \mathrm{~g} \pm 17.3 \mathrm{SD}$ ). Temperature adjustments to reach final experimental conditions did not exceed $1{ }^{\circ} \mathrm{C}$ per $24 \mathrm{~h}$. The protocol of distributing individuals in the single aquaria was identical between both incubations.

Spatial constraints within the culture rooms forced us to isolate individual treatments (polar cod: 0 and $3{ }^{\circ} \mathrm{C}$; Atlantic cod: $12^{\circ} \mathrm{C}$ ) from the total recirculating water body. Nonetheless, each system contained approx. $1200 \mathrm{~L}$ of recirculating seawater preconditioned with respect to temperature and $\mathrm{PCO}_{2}$. Apart from this, setups were identical to those described above. $\mathrm{NH}_{4}{ }^{+}$tests were conducted twice a week using photometric test kits (Macherey-Nagel, Düren, Germany). The critical threshold for water changes was set to $0.4 \mathrm{mg} \mathrm{L}^{-1}$ for $\mathrm{NH}_{4}{ }^{+}$. During the incubation with Atlantic cod, water quality was maintained by biological filter systems in combination with protein skimmers (Sander, Germany) and daily water exchanges $(600 \mathrm{~L})$.

\section{Water chemistry}

The stability of $\mathrm{PCO}_{2}$ conditions was verified by monitoring $\mathrm{pH}$, temperature, and salinity once to twice a week in triplicate in every treatment. For $\mathrm{pH}$ measurements, a $\mathrm{pH}$ meter (pH 3310, WTW, Weilheim, Germany) was calibrated with thermally equilibrated NBS-buffers (2-point calibration). The $\mathrm{pH}$ values were cross-calibrated to total $\mathrm{pH}$ scale using Tris-buffered $\mathrm{pH}$ reference material (Batch 4, Marine Physical Laboratory, University of California, San Diego, CA, USA). Temperature and salinity were measured using a WTW LF 197 multimeter (WTW, Weilheim, Germany).

In combination with the total dissolved inorganic carbon (verified in triplicates) determined by a Seal QuAAtro SFA Analyzer (800 TM, Seal Analytical, Mequon, USA), the $\mathrm{pH}_{\text {tot }}$ values were used to subsequently calculate the seawater carbonate chemistry in the program CO2SYS (Lewis and Wallace 1998), applying the dissociation constants of Mehrbach et al. (1973) refitted by Dickson and Millero (1987) and the $\mathrm{KHSO}_{4}$ constant after Dickson (1990). A summary of water chemistry data is given in Tables 1 and 2 .

\section{Growth experiment}

In total, the growth experiment lasted 130 days (polar cod) and 133 days (Atlantic cod) under constant conditions. For the determination of individual growth rates, each specimen was measured (total length; to the nearest $\mathrm{mm}$ below) and weighed (wet weight; to the nearest $0.1 \mathrm{~g}$ ) on the third day after feeding, three times during the experiment: (1) prior to the transfer into the experimental setup, (2) after the incubation half-time (polar cod, day 60-68; Atlantic cod, day 44-47), and (3) at the end of the incubation period (polar cod, day 109-130; Atlantic cod, day 108-133). For the precise determination of length and weight, the fish were slightly sedated $\left(0.06 \mathrm{~g} \mathrm{~L}^{-1} \mathrm{MS}-222\right)$ prior to measuring. A light cycle of $12: 12 \mathrm{~h}$ was maintained. During day time, the light was dimmed except for the feeding and feed-removing events, as well as during water condition measurements.

Each fish was fed ad libitum once every 4 days using a predetermined amount of high-protein feed pellets (Amber Neptun, $5 \mathrm{~mm}$, Skretting AS, Norway). For a better feed acceptance of polar cod, the pellets were soaked with a fixed amount of sea water $24 \mathrm{~h}$ before feeding. Remaining feed items were removed after several hours, dried for $24 \mathrm{~h}$ at $80{ }^{\circ} \mathrm{C}$, and weighed for the quantification of individual feed intakes. The relative nutrient composition of the pellets was $54.7 \%$ protein, $19.1 \%$ fat, $8.0 \%$ carbohydrates, and $8.5 \%$ moisture. Every single aquarium was cleaned daily from feces and other particles. In the case of feeding days, cleaning happened well before the feeding events.

\section{Respiration measurements}

At the end of the long-term incubation, individual oxygen consumption rates $\left[\dot{M} \mathrm{O}_{2}\right.$; unit: $\left.\mu \mathrm{mol}\left(\min ^{*} \mathrm{~g}\right)^{-1}\right]$ were determined (polar cod, $n=4-6$; Atlantic cod, $n=5-12$ per treatment) using automated intermittent-flow respirometry. Two systems comprising six acryl respiration chambers each (polar cod, 1.8 and 2.2 L; Atlantic cod, 3.9 L) were installed. The respiration chambers were submerged in water of the respective temperature $/ \mathrm{PCO}_{2}$ treatments. A circulating water flow was constantly maintained within the respiration chambers by aid of an aquarium pump $\left(8.2 \mathrm{~L} \mathrm{~min}^{-1}\right)$. A flush pump $\left(5.0 \mathrm{~L} \mathrm{~min}^{-1}\right)$ was used to fully replenish the $\mathrm{O}_{2}$ concentration in the chambers after a measurement period of 15 min (polar cod; Atlantic cod, 3 and $8^{\circ} \mathrm{C}$ ) and $10 \mathrm{~min}$ (Atlantic cod, 12 and $16^{\circ} \mathrm{C}$ ). $\dot{M} \mathrm{O}_{2}$ was measured using optical oxygen probes and recorded with a 10-channel oxygen meter (PreSens Precision Sensing GmbH, Hamburg, Germany; system 1), as well as a four-channel FireStingO2 (Pyro Science GmbH, Aachen, Germany) and two Fibox 3 (PreSens Precision Sensing GmbH, Hamburg, Germany) (system 2). For calibration, the oxygen probes were flushed with nitrogen at room temperature $(0 \%$-calibration), and the $100 \%$-calibration was performed in fully aerated seawater at the respective experimental temperature prior to each round of measurements. Blank measurements detected bacterial background respiration following $\dot{M} \mathrm{O}_{2}$ measurements at each temperature (polar 
cod) or at each temperature/ $\mathrm{PCO}_{2}$ combination (Atlantic cod) during several loops. After subtraction of bacterial respiration (solely detected at $8{ }^{\circ} \mathrm{C}$ for polar cod and $16{ }^{\circ} \mathrm{C}$ for Atlantic cod), the average of the five lowest, consecutive $\dot{M} \mathrm{O}_{2}$ values per individual was used as an estimate of standard metabolic rate (SMR).

The fish were placed in the respiration chambers on the third day after feeding and remained in the chambers for approx. $48 \mathrm{~h}$ to allow for full recovery from handling stress. During the measurement period, non-transparent plastic sheets covered the tanks containing the respiration chambers to reduce potential disturbance. In order to minimize the time of air exposure, weighing was conducted before the fish were placed in the chambers, while length measurements happened after the determination of $\dot{M} \mathrm{O}_{2}$.

\section{Statistical analysis}

The specific growth rate (SGR) per day was calculated in percent of the initial weight according to Jobling (1988):

$\mathrm{SGR}=100 *\left(\ln W_{\text {end }}-\ln W_{\text {start }}\right) *\left(t_{\text {end }}-t_{\text {start }}\right)^{-1}$,

with $W_{\text {start }}$ and $W_{\text {end }}$ being the individual weight in gram at the day $t_{\text {start }}$ and $t_{\text {end }}$, respectively.

The individual feed intake $(\mathrm{F})$ per meal was calculated according to:

$F=\mathrm{hl} * F_{\text {in }}-F_{\text {out }}$

The constant (hl) supports the compensation of different humidity levels of feed pellets before and after drying. The determination of exact humidity levels in feed pellets prior to both incubations revealed slightly divergent correction factors $(\mathrm{hl}=0.8820$ and 1.0227 during the incubation with polar cod and Atlantic cod, respectively). $F_{\text {in }}$ is the amount of feed given to the respective individual per meal, while $F_{\text {out }}$ represents the amount of remaining feed items in gram. Subsequently, the feed intake per body weight (weight at experimental midterm) of each individual throughout the whole experimental period was determined. Furthermore, individual stomachs and their content were weighed the third day after the last feeding event in order to determine the degree of stomach filling (SF) in percent of the stomach weight.

Feed conversion ratio (FCR) of each fish was calculated as the individual weight gain divided by the individual feed intake throughout the experiment.The condition factor (CF) was calculated according to Fulton (1911):

$\mathrm{CF}=100 * W * L_{\mathrm{t}}^{-3}$,

where $W$ is the wet weight in gram and $L_{\mathrm{t}}$ represents the total length in centimeter.
The hepatosomatic index (HSI) was calculated as:

$\mathrm{HSI}=100 * W_{\mathrm{L}} * W^{-1}$,

with $W_{\mathrm{L}}$ representing the liver weight in gram.

The gonadosomatic index (GSI) was determined according to:

$\mathrm{GSI}=100 * W_{\mathrm{G}} * W^{-1}$,

with $W_{\mathrm{G}}$ representing the gonad weight in gram.

Prior to statistical analysis, individuals that were heavily infested by parasites or that died during the incubation due to total refusal of feed were excluded from the data set.

All of the following tests were accomplished using the program $\mathrm{R}$ version 3.0.2 ( $\mathrm{R}$ Core Team 2013). $p<0.05$ is considered as significant. Comparisons of the initial mean weight and length of each fish species between experimental treatments were conducted using a two-way ANOVA. Normal distribution and homoscedasticity were assessed by Shapiro-Wilk tests and Bartlett tests, respectively.

A one-way ANOVA was performed to test for temperature-dependent effects within both $\mathrm{PCO}_{2}$ levels for each species. In case of significant effects, a subsequent Tukey honest significance test for comparisons of the mean was applied. When the data set was characterized by unequal sample sizes and/or heterogeneous variances $(\mathrm{F}, \mathrm{SF}, \mathrm{FCE}$, CF, GSI and SMR), a max-t test (Herberich et al. 2010) was conducted to assess temperature effects within the $\mathrm{PCO}_{2}$ levels. The procedure was performed using a combination of the R packages MULTCOMP (Hothorn et al. 2008) and SANDWICH (Zeileis 2006).

$\mathrm{PCO}_{2}$-dependent effects on SGR, $\mathrm{F}, \mathrm{SF}, \mathrm{FCE}, \mathrm{CF}, \mathrm{HSI}$, GSI, and SMR within each temperature were investigated by aid of Mann-Whitney $U$ tests. In case of significant effects of $\mathrm{PCO}_{2}$, two linear models (full interaction temperature and $P \mathrm{PO}_{2}$, and reduced model $P \mathrm{PO}_{2}$ plus interactive effect temperature: $P \mathrm{PO}_{2}$, respectively) were fitted in order to characterize the effect of hypercapnia in a two-way approach.

When no effects of $\mathrm{PCO}_{2}$ were detected within each species, a second Mann-Whitney $U$ test was done for species comparisons in pooled data across $\mathrm{PCO}_{2}$ treatments for SGR, F, FCE, and SMR at 3 and $8{ }^{\circ} \mathrm{C}$, respectively.

The overall data set from both species was tested for the impact of temperature and $\mathrm{PCO}_{2}$ with the aid of non-metric multidimensional scaling (NMDS). The parameter GSI was excluded in this analysis, because the sex-specific response was shown to outperform every effect of temperature and $\mathrm{PCO}_{2}$ in preliminary tests. Furthermore, HSI was excluded, because HSI caused the discard of the $16{ }^{\circ} \mathrm{C}$ treatments of Atlantic cod in the NMDS, which entailed a reduction in the power of the NMDS. The NMDS showed stress 0.11 for polar cod and 0.08 for Atlantic cod. 


\section{Results}

For both species, initial mean fish weight and length did not show any differences between the treatments.

\section{Mortality}

Polar cod mortality occurred solely at the highest temperature $\left(8{ }^{\circ} \mathrm{C}, n=3, \hat{=} 13.0 \%\right)$ at a rather late stage of the incubation (Fig. 1). Dead Atlantic cod $(n=12$, $\hat{=} 12.5 \%)$ were recorded at all temperatures and $\mathrm{PCO}_{2}$ values with a peak of four individuals $(33.3 \%)$ at $12{ }^{\circ} \mathrm{C} / 390 \mu$ atm. Highest mortality of Atlantic $\operatorname{cod}(n=8, \hat{=} 8.3 \%)$ occurred within the first half of the incubation period (Fig. 1).

\section{Growth}

Growth performance of polar cod did not show any statistically significant temperature effect (Fig. 2). However, under control $\mathrm{PCO}_{2}$ conditions a trend for higher growth at $6{ }^{\circ} \mathrm{C}$ was recognizable $(p=0.07)$. No such temperature trend was found under hypercapnia $(p=0.6)$. The growth rate of Atlantic cod was strongly correlated with temperature (control $\mathrm{PCO}_{2}: p<0.0001$; high $\mathrm{PCO}_{2}: p<0.0001$ ) with a high slope at low and a decreasing slope at higher temperatures (Fig. 2). Therefore, no thermal optimum for growth could be recorded between 3 and $16{ }^{\circ} \mathrm{C}$. A comparison of both species revealed no significant difference in growth rates at $3{ }^{\circ} \mathrm{C}(W=361, p=0.07)$. At $8{ }^{\circ} \mathrm{C}$, the growth performance of Atlantic cod was higher than that of polar $\operatorname{cod}(W=46, p<0.0001)$.

\section{Feed consumption}

For both species, the data set of daily feed consumption per gram body weight was influenced by temperature (Fig. 3). The feed intake of polar cod was lowest at $0{ }^{\circ} \mathrm{C}$ $\left(\right.$ mean $\left.=3.5 \mathrm{mg}\left(\mathrm{g} \mathrm{BW}^{*} \text { day }\right)^{-1}\right)$ compared to the other experimental temperatures, a difference which was more pronounced under hypercapnia (control $P_{2} C_{2}: 0 / 3{ }^{\circ} \mathrm{C}$ $p=0.06,0 / 6{ }^{\circ} \mathrm{C} p=0.04,0 / 8{ }^{\circ} \mathrm{C} p=0.1$; high $P \mathrm{PO}_{2}$ : $\left.0 / 3{ }^{\circ} \mathrm{C} p=0.02,0 / 6{ }^{\circ} \mathrm{C} p=0.02,0 / 8{ }^{\circ} \mathrm{C} p=0.001\right)$. At 3,6 and $8{ }^{\circ} \mathrm{C}$, the feed consumption plateaued and reached an average of $4.8 \mathrm{mg}\left(\mathrm{g} \mathrm{BW}^{*} \text { day }\right)^{-1}$. The degree of stomach filling the third day after feeding in polar cod decreased nonsignificantly with increasing temperature. The daily feed consumption per $\mathrm{g}$ body weight of Atlantic cod rose with temperature, covering a range from 5.1 $\left(3^{\circ} \mathrm{C}\right)$ to $11.2 \mathrm{mg}\left(\mathrm{g} \mathrm{BW}^{*} \mathrm{day}\right)^{-1}\left(16^{\circ} \mathrm{C}\right)$. Under hypercapnia, the slope was progressively less pronounced at high temperatures compared to normocapnic conditions. Atlantic cod consumed distinctly more feed at $8^{\circ} \mathrm{C}(W=46$, $p<0.0001)$ than polar cod. The third day after feeding, stomach contents of Atlantic cod were low except for nonsignificantly higher amounts at $3{ }^{\circ} \mathrm{C}$.

\section{Feed conversion efficiency}

The temperature effect on growth and/or feed intake was also translated into the feed conversion ratio for both
Fig. 1 Total mortality (\%) during long-term incubation including specimens that refused feed consumption from the beginning of the experimental period (excluded in the analysis of further parameters)
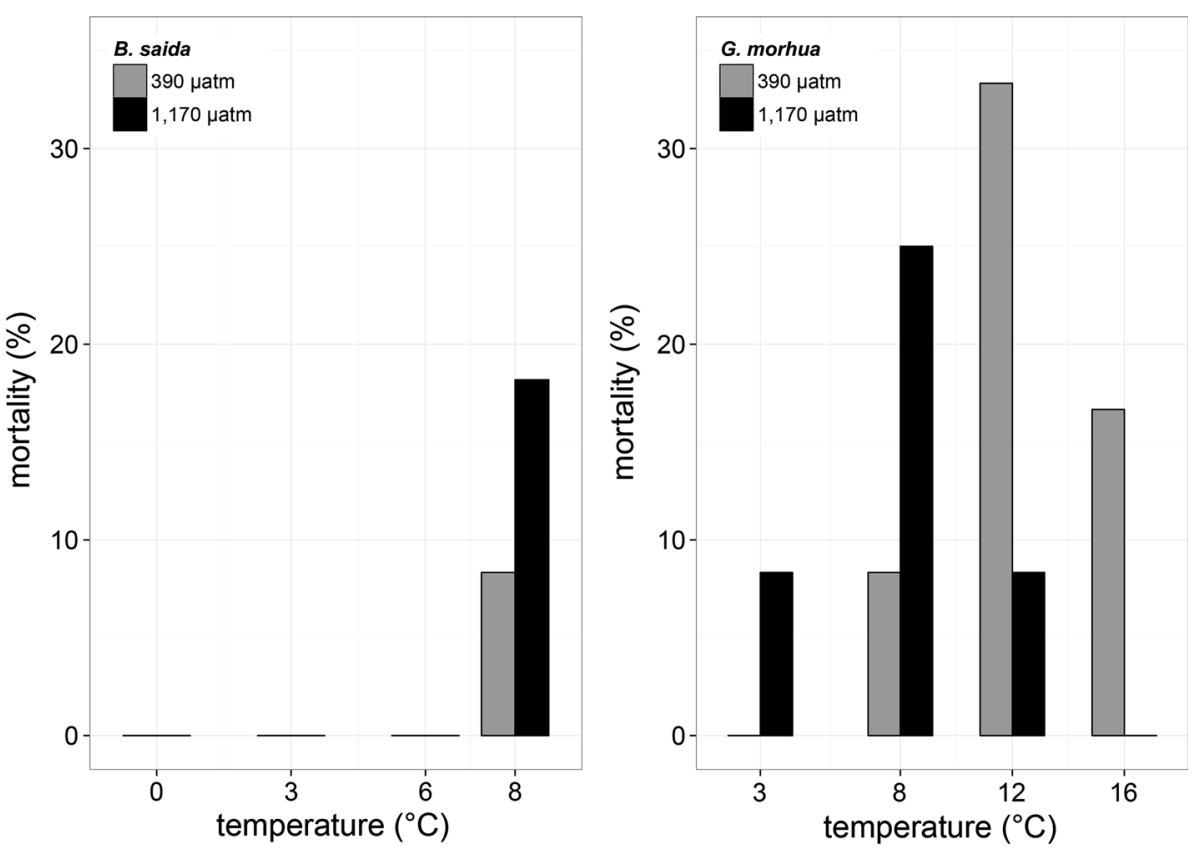
Fig. 2 Specific growth rate (wt $\% \mathrm{~d}^{-1}$ ). Letters comparison of temperature treatments at different $\mathrm{PCO}_{2}$ levels (390 $\mu \mathrm{atm}$ : gray letters; $1170 \mu \mathrm{atm}$ : black letters) in polar cod (Boreogadus saida) (lowercase) and Atlantic cod (Gadus morhua) (uppercase). Asterisks significant difference between species at $8{ }^{\circ} \mathrm{C}$; *** $p<0.001$
Fig. 3 Daily feed consumption $\left(\mathrm{g} \mathrm{BW}^{-1}\right)$. Letters comparison of temperature treatments at different $\mathrm{PCO}_{2}$ levels (390 $\mu \mathrm{atm}$ : gray letters; $1170 \mu \mathrm{atm}$ : black letters) in polar cod (lowercase) and Atlantic cod (uppercase). Asterisks significant difference between species at $8{ }^{\circ} \mathrm{C} ; * * *$ : $p<0.001$
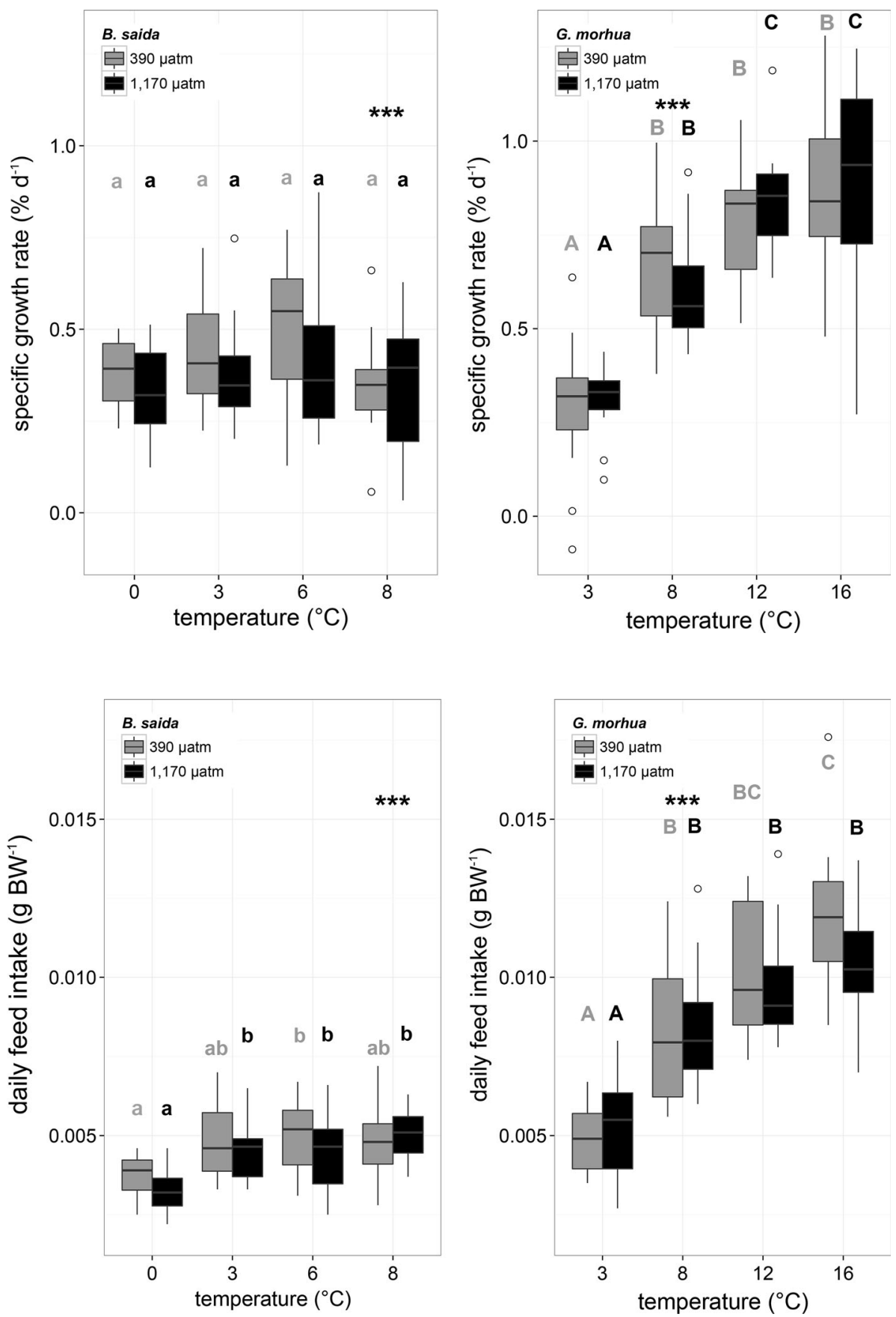

species (Fig. 4). A nonsignificant trend for feed conversion efficiency of polar cod to be highest was recognizable at $0{ }^{\circ} \mathrm{C}$ (mean $=1.18$ ). Feed conversion fell to its lowest value at $8{ }^{\circ} \mathrm{C}$ (mean $=0.71$; control $P^{\circ C_{2}}: 0 / 8{ }^{\circ} \mathrm{C}$ $p=0.001,3 / 8{ }^{\circ} \mathrm{C} p=0.06,6 / 8{ }^{\circ} \mathrm{C} p=0.02$; high $P \mathrm{CO}_{2}$ : $\left.0 / 8{ }^{\circ} \mathrm{C} p=0.02,3 / 8{ }^{\circ} \mathrm{C} p=0.4,6 / 8{ }^{\circ} \mathrm{C} p=0.4\right)$. Atlantic cod revealed a stable feed conversion ratio at 8,12 and $16{ }^{\circ} \mathrm{C}$ with an average value of 0.97 . An exceptionally low feed conversion efficiency was found at $3{ }^{\circ} \mathrm{C}$, which was most distinct under hypercapnia (mean $=0.65$; control $\mathrm{PCO}_{2}: \quad 3 / 8{ }^{\circ} \mathrm{C} \quad p=0.04, \quad 3 / 12{ }^{\circ} \mathrm{C} \quad p=0.1, \quad 3 / 16{ }^{\circ} \mathrm{C}$ $p=0.1 ; \quad$ high $\quad P^{2} \mathrm{CO}_{2}: \quad 3 / 8{ }^{\circ} \mathrm{C} \quad p=0.005, \quad 3 / 12{ }^{\circ} \mathrm{C}$ $\left.p=0.001,3 / 16^{\circ} \mathrm{C} p=0.001\right)$. Therefore, polar cod showed a higher feed conversion ratio at $3{ }^{\circ} \mathrm{C}$ than Atlantic $\operatorname{cod}(W=439, p=0.0005)$, while the opposite was the case at $8{ }^{\circ} \mathrm{C}(W=108, p=0.001)$.

\section{Condition factor and hepatosomatic index}

Polar cod revealed an inverse relationship between $\mathrm{CF}$ and temperature. In contrast, the CF of Atlantic cod increased with temperature (Fig. 5). 
Fig. 4 Feed conversion efficiency. Letters comparison of temperature treatments at different $\mathrm{PCO}_{2}$ levels (390 $\mu \mathrm{atm}$ : gray letters; $1170 \mu \mathrm{atm}$ : black letters) in polar cod (lowercase) and Atlantic cod (uppercase). Asterisks significant difference between species at 3 and $8{ }^{\circ} \mathrm{C}$, respectively; $* *: p<0.01$, ***: $p<0.001$
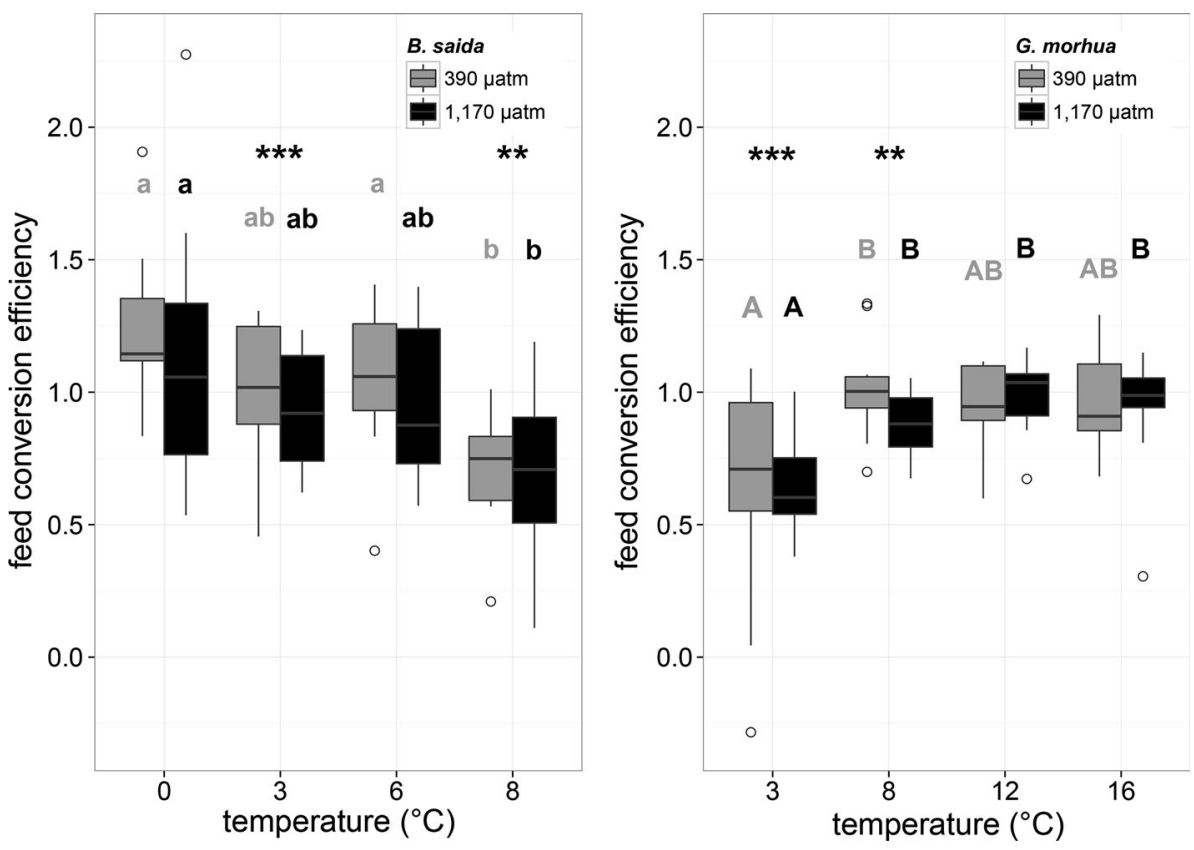

Fig. 5 Condition factor according to Fulton.

Letters comparison of temperature treatments at different $\mathrm{PCO}_{2}$ levels (390 $\mu \mathrm{atm}$ : gray letters; $1170 \mu \mathrm{atm}$ : black letters) in polar cod (lowercase) and Atlantic cod (uppercase)

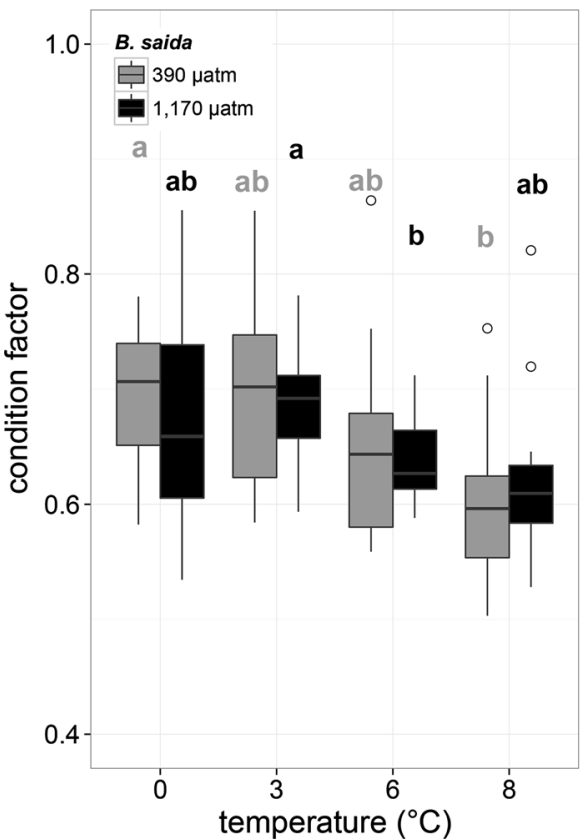

The trend of an increasing HSI at higher temperatures could statistically not be supported for both polar cod and Atlantic cod under normocapnia. Under high $\mathrm{PCO}_{2}$, the increase in HSI with temperature was more pronounced in Atlantic cod $(p<0.0001)$ (Fig. 6), resulting in a significantly higher $\mathrm{HSI}$ under high $\mathrm{PCO}_{2}$ than at control $P \mathrm{CO}_{2}$ at $16{ }^{\circ} \mathrm{C}(W=0, p=0.008)$. The full linear model showed no significant temperature dependency for both species (polar $\operatorname{cod} p=0.14$, Atlantic $\operatorname{cod} p=0.1$ ). The reduced linear model supported the findings on $\mathrm{PCO}_{2}$ impact, taking into consideration the whole range of investigated temperatures and testing the interaction term (polar cod: $p=0.8$; Atlantic cod: $p=0.0004$; Online Resource 1). Atlantic cod shows a significant positive slope (0.34151) in its temperature-dependent trend of HSI under elevated $P \mathrm{CO}_{2}$ matching the trend seen in Fig. 6.

\section{Gonadosomatic index}

Sex determination revealed a majority of immature males $(85.2 \%)$ among polar cod and a slightly larger fraction of immature females (67.2\%) among Atlantic cod. The GSI 
Fig. 6 Hepatosomatic index. Polar cod $(n=8-12)$; Atlantic $\operatorname{cod}(n=5-12)$. Letters comparison of temperature treatments at different $\mathrm{PCO}_{2}$ levels (390 $\mu \mathrm{atm}$ : gray letters; $1170 \mu \mathrm{atm}$ : black letters) in polar cod (lowercase) and Atlantic cod (uppercase). Plus sign significant difference between $\mathrm{PCO}_{2}$ treatments at the same temperatures within the species; $++: p<0.01$. Numbers below $=n$

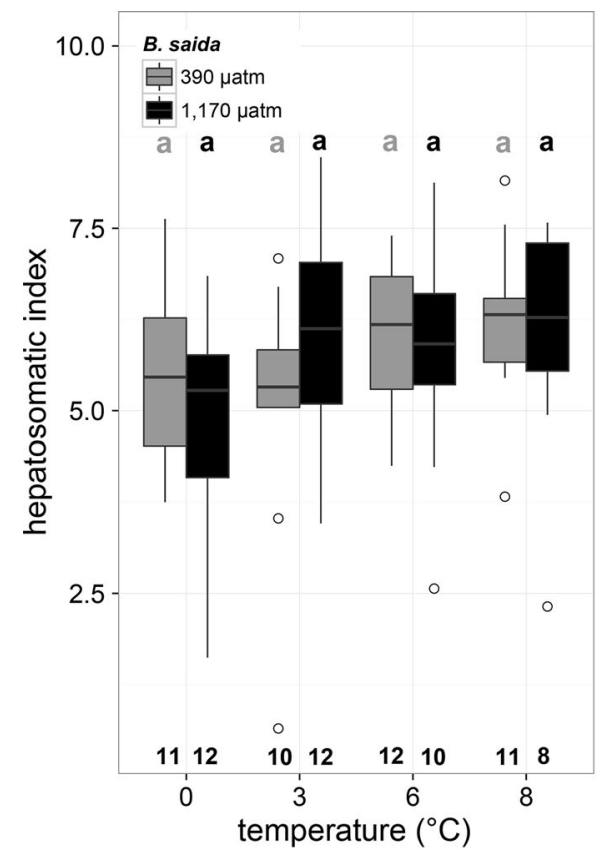

of male polar cod and its variability tended to decrease with increasing temperature. At $0{ }^{\circ} \mathrm{C}$, the average value was $7.31 \%$. The GSI of female Atlantic cod did not show any variation with temperature and appeared to be relatively low (mean $=0.34 \%$; Fig. 7 ; GSI data for complementary sexes of both species are shown in the figure in Online Resource 2).

\section{Standard metabolic rate}

The SMR of both species was strongly affected by temperature (Fig. 8). Polar cod acclimated for 4 months to the respective temperature showed a similar SMR at 0, 3 and $6{ }^{\circ} \mathrm{C}\left(\right.$ mean $\left.=0.053 \mu \mathrm{mol}\left(\mathrm{min}^{*} \mathrm{~g}\right)^{-1}\right)$, but at $8{ }^{\circ} \mathrm{C}, \mathrm{SMR}$ was strongly enhanced $\left(\right.$ mean $\left.=0.080 \mu \mathrm{mol}\left(\mathrm{min}^{*} \mathrm{~g}\right)^{-1}\right)$. This effect was most distinct under normocapnic conditions (control $\mathrm{PCO}_{2}: 0 / 8{ }^{\circ} \mathrm{C} p=0.01,3 / 8{ }^{\circ} \mathrm{C} p=0.002$, $6 / 8{ }^{\circ} \mathrm{C} p=0.02$; high $P_{C O}: 0 / 8{ }^{\circ} \mathrm{C} p=0.02,3 / 8{ }^{\circ} \mathrm{C}$ $\left.p=0.03,6 / 8{ }^{\circ} \mathrm{C} p=0.05\right)$. The SMR of Atlantic cod increased with temperature from $0.030 \quad\left(3^{\circ} \mathrm{C}\right)$ to $0.068 \mu \mathrm{mol}\left(\mathrm{min}^{*} \mathrm{~g}\right)^{-1}\left(16^{\circ} \mathrm{C}\right)$. At both 3 and $8{ }^{\circ} \mathrm{C}$, SMR was distinctly higher in polar cod than in Atlantic cod $\left(3{ }^{\circ} \mathrm{C}: \quad W=247, \quad p<0.0001 ; \quad 8^{\circ} \mathrm{C}: \quad W=189\right.$, $p<0.0001)$.

\section{Effect of temperature and $\mathrm{PCO}_{2}$ on the global data set}

A NMDS analysis of the global data set revealed a significant impact of temperature in both species (polar cod: $p=0.001$, Atlantic cod: $p=0.001$; Fig. 9). A significant effect of $\mathrm{PCO}_{2}$ was only detected in the total data set of polar $\operatorname{cod}(p=0.03)$.

\section{Discussion}

Few studies are available that investigated growth performance of fish under predicted moderate $\mathrm{PCO}_{2}$ conditions. In general, vulnerability of marine teleosts under $\mathrm{PCO}_{2}$ conditions projected for the year 2100 is considered to be low due to excess capacities for acid-base regulation in gill cells (Melzner et al. 2009; Michael et al. 2016). Besides that, the life stages investigated in the present study are less sensitive to changing abiotic conditions than eggs, larvae or spawning life stages (Pörtner and Farrell 2008). Accordingly, neither mortality nor growth performance of polar cod and Atlantic cod were significantly influenced by chronic exposure to hypercapnia in this study. However, nonsignificant trends caused by hypercapnia were found in most of the parameters investigated. As a note of caution, the impact of $\mathrm{PCO}_{2}$ might be reduced by low growth performance due to low-frequency feeding events. In polar cod, the effect of $\mathrm{PCO}_{2}$ was visible in a nonsignificant trend for depressed growth performance under high $\mathrm{PCO}_{2}$ conditions, which was most pronounced at the optimum temperature for growth determined under control conditions $\left(6^{\circ} \mathrm{C}\right)$. Costly compensatory processes in ion and acid-base regulation may cause the decrease in scope for growth. Growth impairment attributed to decreased food consumption under hypercapnic conditions (Smart 1981) may be the result of an uncompensated respiratory acidosis 
Fig. 7 Gonadosomatic index (\%). Polar cod, male $(n=7-11)$; Atlantic cod, female $(n=2-7)$. Letters comparison of temperature treatments at different $\mathrm{PCO}_{2}$ levels (390 $\mu \mathrm{atm}$ : gray letters; $1170 \mu \mathrm{atm}$ : black letters) in polar cod (lowercase) and Atlantic cod (uppercase). Numbers below $=n$
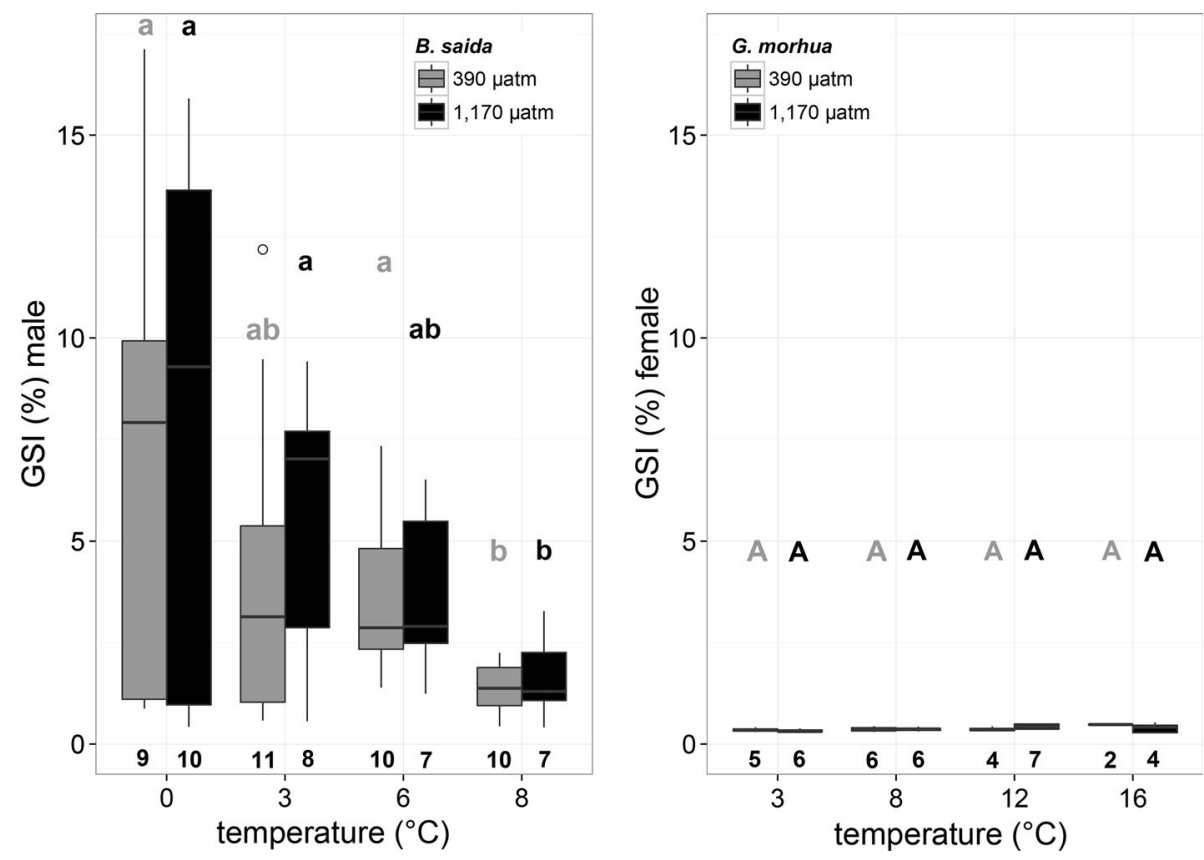

Fig. 8 Standard metabolic rate $\left(\mu \mathrm{mol}\left(\mathrm{min}^{*} \mathrm{~g}\right)^{-1}\right)$. Polar cod $(n=4-6)$; Atlantic cod ( $n=5-12)$. Letters comparison of temperature treatments at different $\mathrm{PCO}_{2}$ levels (390 $\mu \mathrm{atm}:$ gray letters; $1170 \mu \mathrm{atm}$ : black letters) in polar cod (lowercase) and Atlantic cod (uppercase). Asterisks significant difference between species at 3 and $8{ }^{\circ} \mathrm{C}$, respectively; $* * *: p<0.001$. Numbers below $=n$

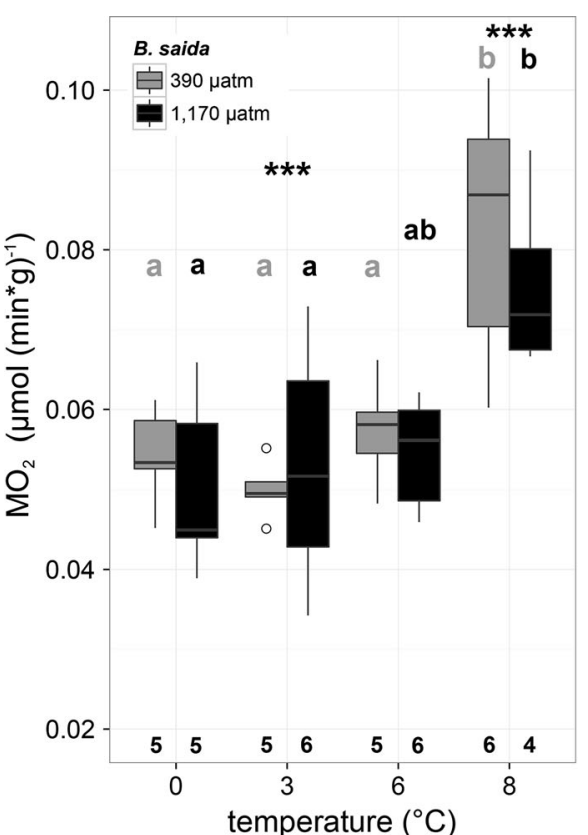

(Crocker and Cech 1996). While no such trend was detected in polar cod, a (nonsignificant) trend for depressed feed intake under hypercapnia was recorded for Atlantic cod and became more prominent in the warmth. Nevertheless, a decline in growth performance or feed conversion efficiency was not detected in Atlantic cod of our study. Furthermore, hypercapnia caused a nonsignificant decrease in metabolic rate as well as a significantly enhanced HSI compared to the control treatment at $16{ }^{\circ} \mathrm{C}$. Liver enlargement might be a compensatory response to potentially impaired lipase activity (Yada et al. 2002) under high $\mathrm{PCO}_{2}$ conditions. An alternative hypothesis attributes the enhanced HSI to an energy surplus, potentially evoked by the amount of energy conserved due to suppressed foraging activity in response to elevated $\mathrm{CO}_{2}$ levels. This hypothesis indicates that the decline in feed uptake of Atlantic cod is less than the decline in energy demand due to foraging activity such that Atlantic cod is thriving slightly better under hypercapnic conditions close to its thermal optimum for growth. Although this 
Fig. 9 Result of non-metric multidimensional scaling. Investigation of effects of temperature and $\mathrm{PCO}_{2}$ on the global data set (excluding GSI and HSI)

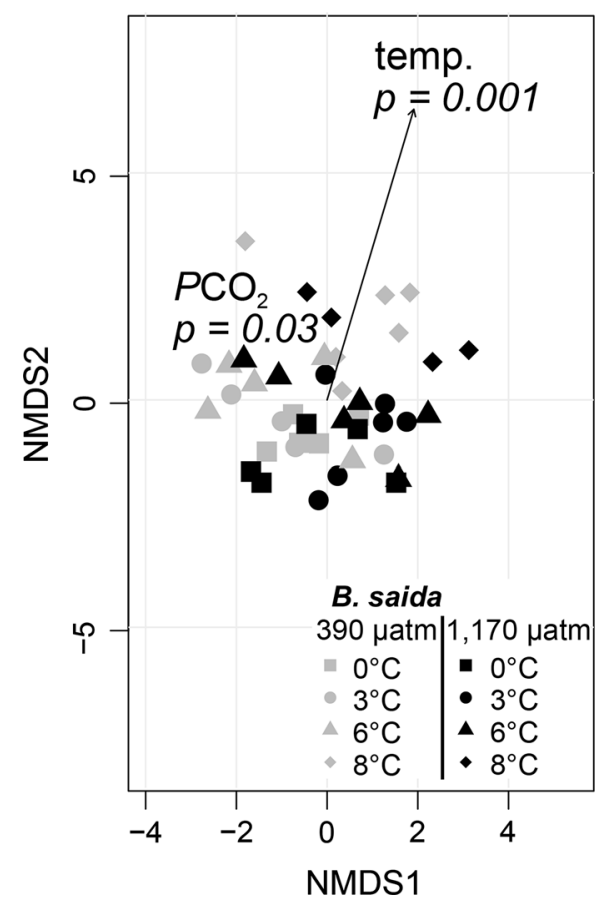

explanation remains speculative, if true it may reflect the wide range of abiotic habitat conditions experienced within the lifetime of Atlantic cod (Neuenfeldt et al. 2009). For comparison, polar cod faces less extreme variations in habitat $P_{2}$ and $P_{2} C_{2}$. Hence, the onset of growth impairment of polar cod under hypercapnia indicates a higher sensitivity of this species to projected future $P \mathrm{PO}_{2}$ values, compared to the more tolerant Arctic population of Atlantic cod. This conclusion is supported by the outcome of the NMDS analysis of the overall data set.

We kept individuals isolated from each other due to cannibalism recorded in the common tanks prior to the start of the experiment. Thereby, their feeding efforts (including foraging and competition) were minimized to below levels typical for their natural environment and aquaculture conditions. This may have improved their growth performance overall and at higher temperatures. The temperature profiles detected here can thus not easily be transferred to the natural environment but provide relative information on the competitive strength of the two species with respect to growth.

For polar cod, mortality occurred exclusively at the highest investigated temperature $\left(8^{\circ} \mathrm{C}\right)$ at a late stage of the experiment. This indicates that moderate constraints on the animal's well-being had long-term effects, classifying $8{ }^{\circ} \mathrm{C}$ as the species' long-term upper thermal tolerance limit. Protective mechanisms such as heat-shock proteins, use of anaerobic metabolism, and antioxidative defense are likely to only support time-limited periods of passive tolerance as outlined by the OCLTT concept (Pörtner 2012).
Elevated baseline energy turnover leads to reduced growth and, finally, via whole organism and cellular functional constraints and stress, reduced survival rates in polar cod at $8{ }^{\circ} \mathrm{C}$. This contrasts earlier findings by Christiansen et al. (1996) who reported that polar cod survives temperatures up to $14{ }^{\circ} \mathrm{C}$ under laboratory conditions. Unfortunately, the authors neither specified the initial acclimation temperature nor the exact duration in the warming protocol. Higher lethal temperatures during shorter-term warming protocols, however, seem to be a general phenomenon and were also found by Peck et al. (2009) in polar species.

Polar cod is known to be a slow growing species (Hop et al. 1997a; Gjøsæter 2009), explaining the limited maximum body length of approx. $30 \mathrm{~cm}$ despite a maximum lifespan of 7 years (Bradstreet et al. 1986; Hop et al. 1997b). Furthermore, growth rates decrease with increasing body weight and age (e.g. Jobling 1983, 1988; Björnsson and Steinarsson 2002; Björnsson et al. 2007). Size-at-age data (Falk-Petersen et al. 1986) at the start of the experiment as well as the maturation stage indicate an age of 2 years for polar cod, whereas Atlantic cod were approx. 1 year old. Thus the comparison of growth rates and further characteristics of the two species in our experiment may be affected by their slightly different positions in the life cycle. The slow growth rate of polar cod (potentially amplified by low-frequency feeding events) likely prevented the detection of statistical differences in body weight increments between temperature treatments. However, due to a trend for increasing growth rates from 0 to $6{ }^{\circ} \mathrm{C}$ under control $\mathrm{PCO}_{2}$ conditions, we assume a growth 
optimum between 3 and $6{ }^{\circ} \mathrm{C}$ that coincides with the temperature preference of this species (Schurmann and Christiansen 1994). At $0{ }^{\circ} \mathrm{C} / 390 \mu \mathrm{atm}$, we recorded a specific growth rate of $0.39 \% \mathrm{~d}^{-1}$, in line with the findings by Christiansen (1995) for polar cod from the Pechora Sea. The initial average weight as well as the feeding frequency was identical in both Christiansen's and our study. In contrast, Hop et al. (1997a) found a relative growth rate $\left(\sim 0.7 \% \mathrm{~d}^{-1}\right)$ at $0{ }^{\circ} \mathrm{C}$ for polar cod from Canadian waters, slightly exceeding the one in our study $\left(0.58 \% \mathrm{~d}^{-1}\right.$, according to the formula in Hop et al. 1997a) despite similar initial body weight. Divergent growth rates relate to the substantially higher daily energy uptake measured by Hop et al. (1997a) $\left(2.058 \mathrm{~kJ} \mathrm{~d}^{-1}\right)$ compared to the present study $\left(1.436 \mathrm{~kJ} \mathrm{~d}^{-1}\right)$. Although lower feeding frequencies may have prevented individuals from exploiting their maximum growth capacity in this study, positive growth clearly demonstrates that the feed intake was sufficient to cover more than baseline costs. It remains to be explored whether growth rates differ between various polar cod populations across the Arctic as well as between fjord and oceanic stocks (Madsen et al. 2015), in similar ways as they differ between Atlantic cod populations (Pörtner et al. 2008).

A depressed feed intake of polar cod at $0{ }^{\circ} \mathrm{C}$ compared to the other experimental temperatures likely contributes to their lower growth rates at cold temperature (Drinkwater 2005). The limits of voluntary feed intake are mirrored by temperature-dependent stomach evacuation rates (Brett 1979; Hop and Tonn 1998). Low temperatures are associated with low stomach evacuation rates (evacuation half times at $-1.42 \pm 0.07{ }^{\circ} \mathrm{C}=36-70 \mathrm{~h}$ ) (Hop and Tonn 1998), high assimilation rates, and low energetic cost of processes competing with growth, resulting in an enhanced feed conversion efficiency at low feed intake. Hence, the thermal optimum for feed conversion results lower than the thermal optimum for growth. Árnason et al. (2009) detected a difference of $3{ }^{\circ} \mathrm{C}$ between these two optima for turbot (Scophthalmus maximus), while our data indicate a difference of as large as $3-6{ }^{\circ} \mathrm{C}$ for polar cod. Although digestion rates, and thus appetite, are known to rise with increasing temperatures (Brett 1979), the daily feed intake reached a plateau at all temperatures investigated above $0{ }^{\circ} \mathrm{C}$, indicating that $18.8 \mathrm{mg}\left(\mathrm{g} \text { wet } \mathrm{BW}^{*} \text { meal }\right)^{-1}$ may represent maximal stomach filling in polar cod from Kongsfjorden (average $\mathrm{BW}=23.3 \mathrm{~g}$ ). This hypothesis implies complete stomach emptying between feeding events above $0{ }^{\circ} \mathrm{C}$; however, stomach inspection confirmed incomplete emptying at the end of the experiment. Based on identical amounts of consumed feed per meal for polar cod at $3-8{ }^{\circ} \mathrm{C}$ and enhanced metabolic rates at $8{ }^{\circ} \mathrm{C}$, we conclude that elevated baseline costs were the constraining factor for both growth and feed conversion at $8{ }^{\circ} \mathrm{C}$.
Furthermore, faster stomach evacuation rates at $8{ }^{\circ} \mathrm{C}$ and accordingly shortened assimilation periods potentially caused decreasing exploitation efficiency of consumed feed in similar ways as described for brown trout (Salmo trutta) by Elliott (1976).

Another parameter interfering with somatic growth is gonadal development. In late September, male polar cod kept at $0{ }^{\circ} \mathrm{C}$ developed a mean GSI of $7.31 \%$, whereas no such trend was visible for the females at the same temperature (mean GSI $=2.09 \%$ ). Hop et al. (1995) reported that gonadal development in male polar cod from the Canadian Arctic maintained at $1{ }^{\circ} \mathrm{C}$ started in August and reached GSI values similar to those in our fish in September. Reproducing males exhibited a GSI of approx. $30 \%$ from December onwards (ibid.). Females show a slow initial increase in gonadal tissue and an exponential gonadal development with a peak in gonad size approximately 2 months after males are ready to spawn (Hop et al. 1995). However, a substantial difference in specific growth rates between sexes before the winter months was not found (Christiansen 1995). The variability in GSI between temperature treatments as well as the mean GSI decreased with increasing temperatures, indicating an unfavorable shift in the energy budget. This trend is also reflected in a continuous decrease in the condition factor at higher temperatures. The lipids needed for gonadal development are very likely mobilized from liver tissue. Therefore, the increasing trend of HSI with temperature might be attributed to a decreasing ability to exploit liver energy reserves in the warmth. Furthermore, gonad development might cause a slight underestimation of growth rate at $0{ }^{\circ} \mathrm{C}$, considering the lower weight of gonadal tissue compared to muscle tissue of identical energy content.

In contrast to the findings for polar cod, mortality among Atlantic cod occurred predominantly at an early stage of the experiment, mainly due to the total refusal of feed, followed by a few occasional deaths until the end of the incubation. As mortality was scattered across treatments, neither temperature nor $\mathrm{PCO}_{2}$ seemed to be the cause for the recorded mortality.

The growth rates of Atlantic cod were directly correlated with temperature and no distinct thermal optimum was found within the investigated temperature range $\left(3-16^{\circ} \mathrm{C}\right)$. Growth optima are size- (Björnsson et al. 2007) and ratiodependent (Brett 1979) and differ slightly between populations (Pörtner et al. 2001, 2008). Björnsson et al. (2007) found an optimum temperature for growth in similar sized $(56.9 \mathrm{~g})$ Islandic cod at $12.1{ }^{\circ} \mathrm{C}$. The low frequency of feeding events may have caused a feed limitation during our experiments with potential consequences for the thermal optimum for growth. According to Brett (1979), the optimum temperature for growth shifts to lower temperatures under restricted food supply. We therefore conclude 
that the temperature optimum for growth for the investigated population of Atlantic cod in the present study is unlikely above $16{ }^{\circ} \mathrm{C}$. The limited scope for locomotion for individuals in the present study may have modified the priorities in energy allocation such that growth takes priority, especially at high temperatures where activity is known to be most pronounced and costly (e.g. Brown et al. 1989). Investigations of spontaneous activity in our fish revealed no significant differences between the temperatures (pers. obs.) supporting the hypothesis of shifted priorities in energy allocation in favor of growth. Nevertheless, Björnsson et al. (2007) recorded an optimum growth rate of $1.75 \% \mathrm{~d}^{-1}\left(12.1{ }^{\circ} \mathrm{C}\right)$, which exceeds the rate in the present study $\left(0.82 \% \mathrm{~d}^{-1}, 12{ }^{\circ} \mathrm{C}\right)$ more than twofold for cod of similar size. Björnsson et al. (2007) fed their fish several times per day, potentially explaining the difference in growth rates. Despite the potential feed limitation in our experiment, we recorded similar daily feed consumption rates compared to a study with higher feeding frequencies: Peck et al. (2003) detected a daily feed intake of $1.62 \%$ (wet $\mathrm{BW}^{*}$ day) ${ }^{-1}$ for Atlantic cod of $7.57 \mathrm{~g}$ at $12{ }^{\circ} \mathrm{C}$ fed one to three times per day with artificial diet $(19.84 \mathrm{~kJ} \text { (g wet wt. })^{-1}$ ). The fish in the present study consumed $1.44 \%$ (wet $\mathrm{BW}^{*}$ day $)^{-1} \quad(15.865 \mathrm{~kJ}$ $(\mathrm{g} \text { wet wt. })^{-1}$ ) at the same temperature and a mean body weight of $40.4 \mathrm{~g}$. Although the percent feed consumption is considered to decrease with increasing body weight, the comparable amounts consumed in both studies indicate a compensation for low feeding frequency by high feed consumption per meal. High feed consumption is supported by complete stomach emptying between the feeding events at this temperature as confirmed by stomach inspections at the end of the experiment. Despite higher rates of stomach emptying (Tyler 1970) and rising metabolic costs with increasing temperatures, both condition factor and HSI increased continuously, indicating an energy surplus. Accordingly, feeding was sufficient to support positive growth at all temperatures. Along similar lines of reasoning, the increasing feed consumption rates per unit body weight at higher temperatures were likely sufficient to cover the higher maintenance costs, indicated by constant feed conversion efficiencies at increasing temperatures. Solely at $3{ }^{\circ} \mathrm{C}$, the feed conversion efficiency appeared to be reduced [by $34.2 \% \quad(390 \mu \mathrm{atm})$ and $30.6 \%$ $(1170 \mu \mathrm{atm})]$. At this temperature, the feed intake is very likely limited by low stomach evacuation rates and low digestion rates. Accordingly, $3{ }^{\circ} \mathrm{C}$ approaches the lower thermal limit of this species" metabolic efficiency, potentially evoked by insufficient capacity of the digestive system (Pörtner 2001). However, cod are still able to exploit this temperature range as the habitat temperatures experienced by adult Atlantic cod from the Barents Sea were found to fall temporarily below $3{ }^{\circ} \mathrm{C}$ (Michalsen et al.
2014). At all comparable temperatures, Björnsson et al. (2001) found higher feed conversion efficiencies for Atlantic cod than recorded in this study, possibly indicating a high plasticity of this species to adapt to different feeding regimes.

Further considerations include a potential functional and genetic difference between different stocks of Atlantic cod. The fish in Björnsson et al. (2007) were hatchery reared and originated from an Icelandic broodstock, while our fish were caught in the area around Svalbard. Growth performance of different cod stocks has been shown to decrease with increasing latitude (Fischer 2002). The selection of specific phenotypes from the larval population at high mortality may cause such functional differences. Although genetic differences in growth performance cannot be eliminated by acclimatization processes (Pörtner et al. 2001), the differences in growth rates of different populations reared under similar conditions appear to be small (Purchase and Brown 2001, cf. Pörtner et al. 2008). Therefore, Björnsson and Steinarsson (2002) considered a genetic contribution to Atlantic cod growth to be less than the influence of environmental factors.

Although the specimens of both species originate from an environment with temperatures well below their optimum for growth, the stenothermal polar cod is very well adapted to the low temperatures, whereas the eurythermal Atlantic cod appears to reach the lower boundaries of its thermal window. Despite higher maximal growth capacity in Atlantic than in polar cod, the better growth performance at low temperatures emphasizes the higher degree of cold adaptation of polar cod than of Atlantic cod coexisting in the same area. Consequently, the majority of polar cod in the present study were caught at temperatures between -1.5 and $3.0{ }^{\circ} \mathrm{C}$ in bottom waters, whereas juvenile Atlantic cod were caught in surface waters at temperatures between 4.0 and $6.0^{\circ} \mathrm{C}$. Hence, the benefit of low predation pressure for polar cod at low temperatures (Brown et al. 1989) seems to outweigh the physiological restrictions. The high feed conversion efficiency at low temperatures enables polar cod to reveal positive growth even with little or temporally restricted food supply. Furthermore, reduced foraging activity involves less exposure to potential predators. In contrast to polar cod, Atlantic cod is well adapted to handle high food abundances (Jensen et al. 1991), indicated by greatly varying feed consumption rates with temperature. Therefore, its growth performance, as well as the temperature optimum for growth in nature, are strongly correlated with food availability (Jobling 1994). The physiology of Atlantic cod seems to be specialized in efficient and fast growth in order to reduce predation pressure at small body size. The feed conversion efficiency of Atlantic cod decreases remarkably in the cold, evoked by a stronger impairment of feed intake compared to the 
decrease in maintenance costs. Nevertheless, adult Atlantic cod can experience and tolerate subzero temperatures for short periods (Michalsen et al. 2014), making them likely candidates to prey upon polar cod in deep, cold water layers in the fjords around Svalbard.

Under projected climate conditions for the year 2100 , growth performance of polar cod is expected to remain unchanged. However, from the present perspective, its feed conversion efficiency can be assumed to decrease progressively. Considering that other temperate fish species are also extending their distribution range to the North, such competition might cause a northward displacement of polar cod. Hop and Gjøsæter (2013) expect the pelagic capelin (Mallotus villosus) and herring (Clupea harengus) as likely invader species replacing polar cod as a key species in the area of investigation. Atlantic cod is expected to thrive under future ocean conditions in the area around Svalbard, provided that its prey species also adapt to the environmental changes or that it is able to switch the species preyed upon. However, the distribution of demersal Atlantic cod is likely constrained by the shelf edge (Hop and Gjøsæter 2013), whereas ice-associated polar cod is found throughout the Arctic Ocean. Ultimately, it is not the increase in annual mean temperature but rather the change in extreme temperatures that will be crucial for a species" settlement (Stachowicz et al. 2002).

In conclusion, the combined drivers ocean acidification and warming (OAW) caused nonsignificant trends in growth performance and SMR of polar cod and in feed consumption and HSI of Atlantic cod. While the performance of polar cod will be impaired under projected water conditions by year 2100, Atlantic cod will thrive, visible in lower amounts of feed necessary for the maintenance of growth performance. The higher tolerance of Atlantic cod to changing water conditions is likely attributed to the wide range of abiotic habitat conditions experienced within its lifetime. Temperature is the predominant environmental factor causing the shift in relative performance by influencing the energy allocation between individual processes in the energy budget of both species. The stenothermal polar cod is specialized in temperatures well below its thermal optimum for growth and can thrive with little food supply, thereby escaping competitive pressure. Atlantic cod is eurythermal and rather displays high plasticity under changing abiotic conditions, but is less competitive in the cold. Hence, we argue that the competitive strength of polar cod is expected to decrease dramatically under future warming and acidification. Therefore, a northward displacement and thereby a decreasing distribution range of polar cod will be the likely consequence of the ongoing distribution shift of Atlantic cod to the north. However, the reported effects may become less pronounced over time depending on potential trans-generational adaptation effects.

Acknowledgments This project was funded through the research program BIOACID (Biological Impacts of Ocean Acidification, phase II) by the German Federal Ministry of Education and Research (BMBF, WP 4.1 and 4.2, FKZ 03F0655B, FKZ 03F0728B). All authors acknowledge funding through the PACES (Polar Regions and Coasts in a Changing Earth System) program of the Alfred Wegener Institute Helmholtz Centre for Polar and Marine Research (AWI). Furthermore, the authors gratefully acknowledge Jasmine Nahrgang and the project Polarisation (Norwegian Research Council, No. 214184/F20) for providing polar cod. We thank the crews of RV Heincke (AWI, funding No. AWI_HE 408_00) and RV Helmer Hanssen (University of Troms $\varnothing$ ) for animal collection. Further, we would like to thank Timo Hirse and Sebastian Berger for technical assistance with the manipulation of $\mathrm{CO}_{2}$ partial pressure, Anette Tillmann, Karim Zanaty, Marcel Machnik, Benjamin Matthei and Fredy Véliz Moraleda for their contribution to the measurements of $\mathrm{pH}$ and DIC, and Christiane Hassenrück for determining the stomach weights of polar cod. We highly appreciate the constructive comments of the editor Dieter Piepenburg, Tony Hickey, Harald Gjøsæter and one anonymous referee on the submitted manuscript.

\section{Compliance with ethical standards}

Conflict of interest The authors declare that they have no conflict of interest.

Ethical approval All procedures performed in the present study were in accordance with the ethical standards of the federal state of Bremen, Germany, and were approved under the reference number 522-27-22/02-00 (113).

\section{References}

Árnason T, Björnsson B, Steinarsson A, Oddgeirsson M (2009) Effects of temperature and body weight on growth rate and feed conversion ratio in turbot (Scophthalmus maximus). Aquaculture 295:218-225

Björnsson B, Steinarsson A (2002) The food-unlimited growth rate of Atlantic cod (Gadus morhua). Can J Fish Aquat Sci 59:494-502

Björnsson B, Steinarsson A, Oddgeirsson M (2001) Optimal temperature for growth and feed conversion of immature cod (Gadus morhua L.). ICES J Mar Sci 58:29-38

Björnsson B, Steinarsson A, Árnason T (2007) Growth model for Atlantic cod (Gadus morhua): effects of temperature and body weight on growth rate. Aquaculture 271:216-226

Bradstreet MSW, Finley KJ, Sekerak AD, Griffiths WB, Evans CR, Fabijan MF, Stallard HE (1986) Aspects of the biology of Arctic cod Boreogadus saida and its importance in Arctic marine food chains. Can Tech Rep Fish Aquat Sci 1491:1-193

Brander KM (1994) Patterns of distribution, spawning, and growth in North Atlantic cod: the utility of inter-regional comparisons. ICES Mar Sci 198:406-413

Brander KM (1995) The effect of temperature on growth of Atlantic cod (Gadus morhua L.). ICES J Mar Sci 52:1-10

Brander KM (2007) The role of growth changes in the decline and recovery of North Atlantic cod stocks since 1970. ICES J Mar Sci 64:211-217

Brander KM (2010) Cod (Gadus morhua) and climate change: processes, productivity and prediction. J Fish Biol 77:1899-1911 
Brander KM, Blom G, Borges MF, Erzini K, Henderson G, MacKenzie BR, Mendes H, Santos AMP, Toresen P (2003) Changes in fish distribution in the eastern North Atlantic: are we seeing a coherent response to changing temperature? ICES Mar Sci 219:261-270

Brett JR (1979) Environmental factors and growth. In: Hoar WS, Randall DJ, Brett JR (eds) Fish physiology, vol 8., Academic PressNew York, NY, pp 599-675

Brown JA, Pepin P, Methven DA, Somerton DC (1989) The feeding, growth and behaviour of juvenile cod, Gadus morhua L., in cold environments. J Fish Biol 35:373-380

Christiansen JS (1995) Food consumption and growth rate variations in male and female polar cod (Boreogadus saida). ICES Council Meeting (Theme Session P) Causes of Observed Variations in Fish Growth P:9

Christiansen JS, Schurmann H, Siikavuopio S (1996) Nonthermal correlates of selected temperature in capelin and polar codcurrent lines of research. ICES Council Meeting (Theme Session H) $\mathrm{H}: 7$

Clark RA, Fox CJ, Viner D, Livermore M (2003) North Sea cod and climate change-modelling the effects of temperature on population dynamics. Global Change Biol 9:1669-1680

Coutant CC (1977) Compilation of temperature preference data. J Fish Res Board Can 34:739-745

Crocker CE, Cech JJ (1996) The effects of hypercapnia on the growth of juvenile white sturgeon, Acipenser transmontanus. Aquaculture 147:293-299

Dickson AG (1990) Standard potential of the reaction: $\mathrm{AgCl}(\mathrm{s})+1 /$ $2 \mathrm{H}_{2}(\mathrm{~g})=\mathrm{Ag}(\mathrm{s})+\mathrm{HCl}(\mathrm{aq})$, and the standard acidity constant of the ion $\mathrm{HSO}_{4}{ }^{-}$in synthetic sea water from 273.15 to 318.15 K. J Chem Thermodyn 22:113-127

Dickson AG, Millero FJ (1987) A comparison of the equilibrium constants for the dissociation of carbonic acid in seawater media. Deep Sea Res 34:1733-1743

Drinkwater KF (2005) The response of Atlantic cod (Gadus morhua) to future climate change. ICES J Mar Sci 62:1327-1337

Drinkwater K (2009) Comparison of the response of Atlantic cod (Gadus morhua) in the high-latitude regions of the North Atlantic during the warm periods of the 1920s-1960s and the 1990s-2000s. Deep Sea Res Pt II 56:2087-2096

Elliott JM (1976) The energetics of feeding, metabolism and growth of brown trout (Salmo trutta L.) in relation to body weight, water temperature and ration size. J Anim Ecol 45:923-948

Falk-Petersen I-B, Frivoll V, Gulliksen B, Haug T (1986) Occurrence and size/age relations of polar cod, Boreogadus saida (Lepechin), in Spitsbergen coastal waters. Sarsia 71:235-245

Fischer T (2002) The effects of climate induced temperature changes on cod (Gadus morhua L.): Linking ecological and physiological investigations. Dissertation, University of Bremen

Fivelstad S, Haavik H, Løvik G, Olsen AB (1998) Sublethal effects and safe levels of carbon dioxide in seawater for Atlantic salmon postsmolts (Salmo salar L.): ion regulation and growth. Aquaculture 160:305-316

Fivelstad S, Olsen AB, Kløften H, Ski H, Stefansson S (1999) Effects of carbon dioxide on Atlantic salmon (Salmo salar L.) smolts at constant $\mathrm{pH}$ in bicarbonate rich freshwater. Aquaculture 178:171-187

Fivelstad S, Waagb $\varnothing$ R, Stefansson S, Olsen AB (2007) Impacts of elevated water carbon dioxide partial pressure at two temperatures on Atlantic salmon (Salmo salar L.) parr growth and haematology. Aquaculture 269:241-249

Foss A, Røsnes BA, Øiestad V (2003) Graded environmental hypercapnia in juvenile spotted wolffish (Anarhichas minor Olafsen): effects on growth, food conversion efficiency and nephrocalcinosis. Aquaculture 220:607-617
Fulton TW (1911) The Sovereignty of the Sea: an historical account of the claims of england to the dominion of the British Seas, and of the Evolution of the territorial waters, with special reference to the rights of fishing and the naval salute. The Lawbook Exchange Ltd, New Jersey

Gjøsæter H (2009) Commercial fisheries (fish, seafood, marine mammals). In: Sakshaug E, Johnsen G, Kovacs KM (eds) Ecosystem Barents Sea. Tapir Academic Press, Trondheim, pp 373-414

Grebmeier JM, Overland JE, Moore SE, Farley EV, Carmack EC, Cooper LW, Frey KE, Helle JH, McLaughlin FA, McNutt SL (2006) A major ecosystem shift in the northern Bering Sea. Science 311:1461-1464

Herberich E, Sikorski J, Hothorn T (2010) A robust procedure for comparing multiple means under heteroscedasticity in unbalanced designs. PLoS One 5:e9788. doi:10.1371/journal.pone.0009788

Holst JC, McDonald A (2000) FISH-LIFT: a device for sampling live fish with trawls. Fish Res 48:87-91

Hop H, Gjøsæter H (2013) Polar cod (Boreogadus saida) and capelin (Mallotus villosus) as key species in marine food webs of the Arctic and the Barents Sea. Mar Biol Res 9:878-894

Hop H, Tonn WM (1998) Gastric evacuation rates and daily rations of Arctic cod (Boreogadus saida) at low temperatures. Polar Biol 19:293-301

Hop H, Trudeau VL, Graham M (1995) Spawning energetics of Arctic cod (Boreogadus saida) in relation to seasonal development of the ovary and plasma sex steroid levels. Can J Fish Aquat Sci 52:541-550

Hop H, Tonn WM, Welch HE (1997a) Bioenergetics of Arctic cod (Boreogadus saida) at low temperatures. Can J Fish Aquat Sci 54:1772-1784

Hop H, Welch HE, Crawford RE (1997b) Population structure and feeding ecology of Arctic cod (Boreogadus saida) schools in the Canadian High Arctic. In: Reynolds J (ed) Fish ecology in Arctic North America, American Fisheries Society Symposium 19. American Fisheries Society, Bethesda, pp 68-80

Hothorn T, Bretz F, Westfall P (2008) Simultaneous inference in general parametric models. Biom J 50:346-363

Jensen T, Ugland KI, Anstensrud M (1991) Aspects of growth in Arctic cod, Boreogadus saida (Lepechin 1773). Polar Res 10:547-552

Jobling M (1983) Growth studies with fish-overcoming the problems of size variation. J Fish Biol 22:153-157

Jobling M (1988) A review of the physiological and nutritional energetics of cod, Gadus morhua L., with particular reference to growth under farmed conditions. Aquaculture 70:1-19

Jobling M (1994) Fish bioenergetics. Chapman and Hall, London

Kjesbu OS, Bogstad B, Devine JA, Gjøsæter H, Howell D, Ingvaldsen RB, Nash RD, Skjæraasen JE (2014) Synergies between climate and management for Atlantic cod fisheries at high latitudes. P Natl Acad Sci USA 111:3478-3483

Koehn RK, Shumway SE (1982) A genetic/physiological explanation for differential growth rate among individuals of the American oyster, Crassostrea virginica (Gmelin). Mar Biol Lett 3:35-42

Lewis E, Wallace DWR (1998) Program developed for $\mathrm{CO}_{2}$ system calculations. Carbon Dioxide Information Analysis Center, Oak Ridge National Laboratory, Oak Ridge, TN. ORNL/CDIAC-105

Madsen ML, Nelson RJ, Fevolden SE, Christiansen JS, Præbel K (2015) Population genetic analysis of Euro-Arctic polar cod Boreogadus saida suggests fjord and oceanic structuring. Polar Biol. doi:10.1007/s00300-015-1812-y

Malmberg S, Blindheim J (1994) Climate, cod, and capelin in northern waters. ICES Mar Sci 198:297-310

Mehrbach C, Culberson CH, Hawley JE, Pytkowicz RN (1973) Measurement of the apparent dissociation constants of carbonic 
acid in seawater at atmospheric pressure. Limnol Oceanogr 18:897-907

Melzner F, Gutowska MA, Langenbuch M, Dupont S, Lucassen M, Thorndyke MC, Bleich M, Pörtner HO (2009) Physiological basis for high $\mathrm{CO}_{2}$ tolerance in marine ectothermic animals: preadaptation through lifestyle and ontogeny? Biogeosciences 6:2313-2331

Michael K, Kreiss CM, Hu MY, Koschnick N, Bickmeyer U, Dupont S, Pörtner HO, Lucassen M (2016) Adjustments of molecular key components of branchial ion and $\mathrm{pH}$ regulation in Atlantic cod (Gadus morhua) in response to ocean acidification and warming. Comp Biochem Phys B 193:33-46

Michalsen K, Johansen T, Subbey S, Beck A (2014) Linking tagging technology and molecular genetics to gain insight in the spatial dynamics of two stocks of cod in Northeast Atlantic waters. ICES J Mar Sci 71:1417-1432

Moran D, Støttrup JG (2011) The effect of carbon dioxide on growth of juvenile Atlantic cod Gadus morhua L. Aquat Toxicol 102:24-30

Neuenfeldt S, Andersen KH, Hinrichsen HH (2009) Some Atlantic cod Gadus morhua in the Baltic Sea visit hypoxic water briefly but often. J Fish Biol 75:290-294

Olsen E, Aanes S, Mehl S, Holst JC, Aglen A, Gjøsæter H (2010) Cod, haddock, saithe, herring, and capelin in the Barents Sea and adjacent waters: a review of the biological value of the area. ICES J Mar Sci 67:87-101

Ottersen G, Michalsen K, Nakken O (1998) Ambient temperature and distribution of north-east Arctic cod. ICES J Mar Sci 55:67-85

Parmesan C (2006) Ecological and evolutionary responses to recent climate change. Annu Rev Ecol Evol S 37:637-669

Peck MA, Buckley LJ, Caldarone EM, Bengtson DA (2003) Effects of food consumption and temperature on growth rate and biochemical-based indicators of growth in early juvenile Atlantic cod Gadus morhua and haddock Melanogrammus aeglefinus. Mar Ecol Prog Ser 251:233-243

Peck LS, Clark MS, Morley SA, Massey A, Rossetti H (2009) Animal temperature limits and ecological relevance: effects of size, activity and rates of change. Funct Ecol 23:248-256

Perry AL, Low PJ, Ellis JR, Reynolds JD (2005) Climate change and distribution shifts in marine fishes. Science 308:1912-1915

Planque B, Frédou T (1999) Temperature and the recruitment of Atlantic cod (Gadus morhua). Can J Fish Aquat Sci 56:2069-2077

Pörtner H (2001) Climate change and temperature-dependent biogeography: oxygen limitation of thermal tolerance in animals. Naturwissenschaften 88:137-146

Pörtner HO (2002) Climate variations and the physiological basis of temperature dependent biogeography: systemic to molecular hierarchy of thermal tolerance in animals. Comp Biochem Phys A $132: 739-761$

Pörtner HO (2010) Oxygen-and capacity-limitation of thermal tolerance: a matrix for integrating climate-related stressor effects in marine ecosystems. J Exp Biol 213:881-893

Pörtner HO (2012) Integrating climate-related stressor effects on marine organisms: unifying principles linking molecule to ecosystem-level changes. Mar Ecol Prog Ser 470:273-290

Pörtner HO, Farrell AP (2008) Physiology and climate change. Science 322:690-692

Pörtner HO, Knust R (2007) Climate change affects marine fishes through the oxygen limitation of thermal tolerance. Science 315:95-97

Pörtner HO, Peck MA (2010) Climate change effects on fishes and fisheries: towards a cause-and-effect understanding. J Fish Biol 77:1745-1779

Pörtner HO, Berdal B, Blust R, Brix O, Colosimo A, De Wachter B, Giuliani A, Johansen T, Fischer T, Knust R, Lannig G, Naevdal
G, Nedenes A, Nyhammer G, Satoris FJ, Serendero I, Sirabella P, Thorkildsen S, Zakhartsev M (2001) Climate induced temperature effects on growth performance, fecundity and recruitment in marine fish: developing a hypothesis for cause and effect relationships in Atlantic cod (Gadus morhua) and common eelpout (Zoarces viviparus). Cont Shelf Res 21:1975-1997

Pörtner HO, Langenbuch M, Michaelidis B (2005) Synergistic effects of temperature extremes, hypoxia, and increases in $\mathrm{CO}_{2}$ on marine animals: From Earth history to global change. J Geophys Res Oceans 110:C09S10

Pörtner HO, Bock C, Knust R, Lannig G, Lucassen M, Mark FC, Sartoris FJ (2008) Cod and climate in a latitudinal cline: physiological analyses of climate effects in marine fishes. Clim Res 37:253-270

Pörtner H-O, Karl DM, Boyd PW, Cheung WWL, Lluch-Cota SE, Nojiri Y, Schmidt DN, Zavialov PO (2014) Ocean systems. In: Field CB, Barros VR, Dokken DJ, Mach KJ, Mastrandrea MD, Bilir TE, Chatterjee M, Ebi KL, Estrada YO, Genova RC, Girma B, Kissel ES, Levy AN, MacCracken S, Mastrandrea PR, White LL (eds.) Climate change 2014: impacts, adaptation, and vulnerability. Part A: global and sectoral aspects. Contribution of working group II to the Fifth assessment report of the intergovernmental panel on climate change, Cambridge University Press, Cambridge and New York, NY, pp 411-484

Purchase CF, Brown JA (2001) Stock-specific changes in growth rates, food conversion efficiencies, and energy allocation in response to temperature change in juvenile Atlantic cod. J Fish Biol 58:36-52

R Core Team (2013) R: a language and environment for statistical computing. R Foundation for Statistical Computing, Vienna, Austria. URL http://www.R-project.org/

Renaud PE, Berge J, Varpe Ø, Lønne OJ, Nahrgang J, Ottesen C, Hallanger I (2012) Is the poleward expansion by Atlantic cod and haddock threatening native polar cod, Boreogadus saida? Polar Biol 35:401-412

Schurmann H, Christiansen JS (1994) Behavioral thermoregulation and swimming activity of two Arctic teleosts (subfamily Gadinae)-the polar cod (Boreogadus saida) and the navaga (Eleginus navaga). J Therm Biol 19:207-212

Scott JS (1982) Depth, temperature and salinity preferences of common fishes of the Scotian Shelf. J Northw Atl Fish Sci 3:29-39

Sekerak AD (1982) Young-of-the-year cod (Boreogadus) in lancaster sound and western Baffin Bay. Arctic 35:75-87

Smart GR (1981) Aspects of water quality producing stress in intensive fish culture. In: Pickering AD (ed) Stress and fish. Academic Press, London, pp 277-293

Stachowicz JJ, Terwin JR, Whitlatch RB, Osman RW (2002) Linking climate change and biological invasions: ocean warming facilitates nonindigenous species invasions. P Natl Acad Sci 99:15497-15500

Tyler AV (1970) Rates of gastric emptying in young cod. J Fish Res Board Can 27:1177-1189

Welch HE, Crawford RE, Hop H (1993) Occurrence of Arctic cod (Boreogadus saida) schools and their vulnerability to predation in the Canadian High Arctic. Arctic 46:331-339

Yada T, Moriyama S, Suzuki Y, Azuma T, Takahashi A, Hirose S, Naito N (2002) Relationships between obesity and metabolic hormones in the "cobalt" variant of rainbow trout. Gen Comp Endocr 128:36-43

Zeileis A (2006) Object-Oriented Computation of Sandwich Estimators. J Stat Softw 16:1-16. URL http://www.jstatsoft.org/v16/ i09/ 